\title{
Producing interventions for AIDS-affected young people in Lesotho's schools: scalar relations and power differentials
}

\section{Nicola Ansell}

\begin{abstract}
Children and youth are a key target group for interventions to address southern Africa's AIDS pandemic. Such interventions are frequently implemented through schools, and are often complex products of negotiation between a range of institutional actors including international agencies, NGOs, government departments and individual schools. These institutions not only stand in different (horizontally scaled) spatial relationships to students in schools; they also appear to operate at different hierarchical levels. Empirical research with policy makers and practitioners in Lesotho, however, reveals how interventions are produced through flows of knowledge, funding and personnel within and between institutions that make it difficult to assert that any intervention is manifestly more international or more local than any other. Scale theory offers the metaphor of a network or web which usefully serves to move attention away from discrete organisations, sectors and scalar positionings and onto the relationships and flows between them. Nevertheless, organisations and development interventions are often partly structured in scalar hierarchical ways that express substantive power differentials and shape the forms of interaction that take place, albeit not binding them to strict binaries or nested hierarchies. A modified network metaphor is useful in aiding understanding of how particular interventions are produced through intermeshing scales and diverse fluid interactions, and why they take the form they do.
\end{abstract}

Key words: development interventions; state/civil society relations; aid; NGOs; scale; schools; AIDS; Lesotho

\section{Introduction}

Over the past decade there have been a number of shifts in the discourse and practice of 'development'. These shifts encompass both changes in the favoured sectors (a greater role for the state alongside changing expectations of civil society) and in the scaling of development interventions (renewed emphasis on 'national' ownership, and on decentralisation to district and local levels). Yet while the changing roles of state and voluntary sectors have featured prominently in analysis, there has been remarkably little attention to the changing scales of development intervention or to the interscalar relationships of state and civil society in Africa. In this paper I argue that not only is it inaccurate to regard development interventions as pertaining strictly to either 'state' or 'civil society' (Bebbington 2004; Mercer 2002; Mohan 2002), but to characterise 
them in relation to a global/local binary, or nested 'international', 'national' and 'local' levels, is equally oversimplistic. Such terms fail to capture the multiple interactions between and within sectors and scales that produce interventions.

The paper draws on five examples of non-governmental organisations that are working to address the impacts of AIDS on young people in the school sector in Lesotho, a small southern African nation with a very high AIDS-prevalence. Specifically, I explore their production of interventions to address AIDS, highlighting their sectoral and scalar complexity. Developments in the geographical literature on scale prove useful in shedding light on these complexities, challenging conventional expectations concerning the scalar structuring of governance. Consideration of the function of networks and flows rather than territorially ordered relationships focuses attention on the roles played by flows of knowledge, funding and personnel within and between institutions that make it difficult to assert that any intervention is manifestly more international or more local than any other. Importantly, however, some flows (notably of funding) are more constrained and unidirectional than others, and significant power differentials are expressed and reinforced through the flows. These partly reflect imagined and organisational scalar structures that persist and interact, while not operating as fixed and enduring constraints. Scale theory thus serves as a valuable tool to move attention away from isolated organisations, sectors and scales and onto the relationships and flows between them, aiding understanding of how particular interventions are produced and why they take the form they do. However, it is important not to dismiss fully the role of scale in shaping these relationships and to incorporate into explanations of interventions the role played by multiple interacting scalar structures.

The paper begins by contextualising the research, firstly in relation to changes currently taking place in the relationships between aid donors, states and civil society in Africa and secondly in relation to developments in the theorisation of scale. The research and its setting are introduced, and attention given to the sectoral and scalar ambiguity of the education sector in Lesotho. The five specific cases are considered, with discussion focusing around the flows of personnel, ideas and money that are involved, and the forms of scalar structuration that affect these. The paper concludes by reviewing the implications for studies of post-Washington consensus development interventions and for debates around scale.

\section{State and civil society in Africa: changing sectors, changing scales}

Recent decades have witnessed a series of shifts in the sectors and types of organisations involved in development interventions. Prior to the 1980s, development aid flowed from Western donor 
states and international institutions directly to African governments. From the early 1980s, however, there was a broad change in emphasis away from the state towards the nongovernmental sector. This shift entailed a scalar imaginary. It was instigated by global financial institutions, notably the World Bank and IMF, whose neo-liberal ideology (labelled the Washington consensus) of reliance on market forces and minimisation of state intervention and expenditure became dominant among both multilateral and bilateral donors (Fine 200I). Development policies became globally more uniform, with less national level specificity. Moreover, as funding switched, international NGOs grew in size and local NGOs (those operating in one country), especially social welfare organisations, proliferated (Hudock 1999).

The movement of funding toward non-governmental organisations (NGOs) to undertake development work reflected neo-liberal ideology. Operating as market-based actors in competition for funds, NGOs fitted the ideology in sectors where commercial markets were not well developed (Lawson 2007). Significantly, the advantages of NGOs were also envisaged in scalar terms. While they might have a national or international remit, NGOs were often seen as inherently closer to the 'local'. In terms of service delivery, they were said to be better than governments at reaching the poor; securing beneficiaries' participation in development activities; focusing on processes and not outcomes alone; responding flexibly to needs; working with local institutions; and working on the basis of field realities rather than outside analyses (Fowler 1988). These envisaged advantages did not always correspond to empirical reality in terms of efficiently addressing the needs and interests of the poor (Goetz 1996; Simon and Närman 1999).

While the switch toward the non-governmental sector may have been imagined as a shift of international funding away from the national level of government toward a more local engagement with poor people, there were many other scalar relationships involved. NGOs are themselves commonly characterised as international, national or local (though the latter may be termed Community-Based Organisations and there are NGOs with remits at intervening scalar levels, notably sub-national and supranational regions). 'International' NGOs generally have head offices in Western countries and operate in several southern countries. National NGOs or 'southern' NGOs operate in one or more southern countries. Unlike governments, however, NGO operations seldom span entire territories. Instead they are engaged to deliver services in particular towns or districts on a 'project' basis: an approach that has been widely criticised for leading to lack of coordination, fragmentation and duplication of effort (Cassels and Janovsky 1998). 
Moreover, although popularly regarded as autonomous, NGOs cannot be understood as isolated units, without recognising the relationships that sustain them and give them meaning (Bebbington 2004) - relationships with funding bodies, beneficiaries and increasingly with national governments. These relationships span space and are often viewed in scalar terms. NGOs' activities are strongly shaped by their funding sources, and relationships with funders are of crucial importance and are often embedded in international networks (Bebbington 2004), irrespective of whether an NGO is itself 'international'. Although NGOs receive funding from a variety of sources, their increasing reliance on funding from bilateral and multilateral donors (Hulme and Edwards 1997) diminished the autonomous existence imagined by their advocates. Where NGOs receive all their funds from donors to carry out donor programmes with groups that donors select, NGOs are effectively contractors, operating as extensions of the donor agency (Hudock 1999). Such instances raise the question of whether a southern NGO remains in any sense a nationally-scaled actor.

NGOs also have significant relationships with other NGOs, which again have a scalar dimension. From the early 1980s it was common for northern NGOs to support 'partner' southern NGOs. Despite the label 'partnership', southern NGOs were structurally dependent on northern NGOs (Närman 1999). In turn, the northern NGOs depended on funding sources and while many aspired to more horizontal relationships with southern NGOs, their own funders attached conditions that they had to pass on (Hudock 1999). Today, this 'partnership' model is in decline, as southern NGOs are becoming professionalised and increasingly able to secure funding directly from donors (Lewis 1998). The dependence on the north nonetheless remains and tends to tie southern NGOs to northern views of development (Fowler 2000).

The past decade has seen a new set of transformations in the sectoral and scalar enactment of international development. These partly respond to a growing critique of NGOs: concerns that the project approach is inefficient and that large NGO bureaucracies that sit parallel to, and bypass, the state in service provision threaten 'good governance' by undermining the authority of elected governments. Donors began to move away from their fiercely anti-state agendas and by the late-1990s even the World Bank embraced what has become known as the post-Washington consensus (Fine 200I). Once again the shift was instigated internationally - this time increasing uniformity in the approaches taken by different donors (Simon and Närman 1999) culminated in an international agreement: the 2005 Paris Declaration on Aid Effectiveness.

Today the state is again celebrated as a key actor in development. Both international funding agencies and bilateral donors have been promulgating ideas of partnership with, and ownership by, 
national governments in development interventions (Buchert 2002). The UK Department for International Development (DFID) has declared itself in favour of 'nationally owned poverty reduction strategies ... moving towards providing financial support directly to recipient government budgets using their own systems' (DFID 2000: 93). This appears to signal a symbolic embrace of both the role of the state and also the significance of the national level.

In practical terms, this shift is apparent in the return to bilateral agreements since the late 1990s, with budgetary support the dominant mode of desired delivery of aid by most donors in Africa (Unwin 2004). Direct budget support is favoured by donors over project aid as it is quicker to disburse (Quartey 2005), and easier to manage (Smith 2005).' Rather than general budget support, some donors elect to support particular sectors. Within the broad framework of the Paris Declaration, Sector-Wide Approaches (SWAps) are employed to coordinating donor funding to a particular sector. The idea is that, 'all significant funding for the sector supports a single sector policy and expenditure programme, under Government leadership' (Brown et al 200I: 7). By the early $21^{\text {st }}$ century, the SWAps concept had the support of the World Bank, WHO and key bilateral donors (Hill 2002).

Direct budget support and SWAps may appear to indicate a reversion to purely state-led approaches to development, and sidelining of civil society. This is not the intention: the Paris Declaration states that '[a]id at its most effective is harnessed to plans owned by beneficiaries, channelled through their own systems, with progress indicators agreed and reviewed by all stakeholders' (Armon 2007: 653). These stakeholders, or partners, include governments, the private sector, civil society, NGOs and voluntary organisations. Nor have donors stepped back from involvement. SWAps do not allow recipient governments freedom to spend aid as they choose. In exchange for relinquishing the opportunity to select projects according to their own priorities, 'donors gain a voice (but not a controlling interest) in the process of developing national ... policies, and in decisions about how not only external but also domestic resources are allocated' (Cassels and Janovsky 1998: 1778). In theory donors focus on facilitation and progressively become less involved (Smith 2005), but in practice influence is retained: in the Bangladesh health SWAp, donors tended to dominate dialogue, although without necessarily dominating the national government's actual strategy (White 2007).

\footnotetext{
' The break with the past should not be exaggerated: in the 1980s, for instance, the World Bank shifted from traditional project lending towards policy-based programme lending in Ghana (Quartey 2005), and although budgetary support is increasing, much aid is still directed towards specific approved programmes.
} 
The level of involvement of stakeholders beyond governments and donor agencies in SWAps is varied and the subject of some debate. In the education sector, 'local stakeholders' are often understood to mean national government, and the process tends to exclude other important actors in the sector such as representatives of NGOs, CSOs or end-users of education (students, parents, teachers) or their organisations (Buchert 2002). Where civil society organisations do become involved in SWAps and similar policy processes, they may be used by government purely to demonstrate 'good governance' to donor organisations, or donors and international NGOs may cherry-pick a selection of elite NGOs for involvement, excluding the majority (Mercer 2003), and in particular those engaged in political protest or proposing alternatives to broadly neoliberal orthodoxy (Lawson 2007). Increasingly funding agencies provide governments with funds that are to be distributed to NGOs to undertake service delivery. These changes in funding modalities may force such organisations to be more dependent on government and thereby less able to hold governments to account, even though donors have promoted this as a key role for civil society (Lister and Nyamugasira 2003). Theorisations of civil society have largely ignored these reciprocal linkages between state and society (Mohan 2002).

Alongside SWAps have emerged a variety of new types of organisation. New funders such as the Global Fund to Fight AIDS, Malaria and Tuberculosis, envisaged as a cross-sectoral partnership and the US government's Presidential Emergency Plan for AIDS Relief (PEPFAR), which falls outside USAID, have disease specific remits and have their own ways of working with governments and other organisations, although these are tailored to individual countries. There are also coalitions of national NGOs and regional agencies supported by donor funding that seek to inform policy on particular issues across several states.

The growing role for the nation state in development intervention is not the only form of rescaling taking place. Over the past 20 years, African states have been encouraged to decentralise government, ${ }^{2}$ transferring authority and resources away from the central state towards more peripheral bodies (Olowu 200I). In the 1990s seventy countries worldwide launched decentralisation policies (Sperfeld 2006), with a number of African countries following, or intensifying their efforts much more recently (Lesotho's first local government elections took place in 2005). In contrast to SWAps which almost exclusively involve national level 'partnerships', decentralisation has focused on the district level (Elsey et al 2005). This too was partly a response to pressure from overseas donors: the EU and several European bilateral donors through

\footnotetext{
${ }^{2}$ This is not an entirely new phenomenon - there were several waves of decentralisation in Africa through the twentieth century, although African states arguably remain the most centralised worldwide (Olowu 200I).
} 
‘decentralised cooperation' programmes, sought to work with private, non-governmental and local government bodies, although there were also domestic pressures from non-governmental actors (Olowu 200I). Decentralisation was believed to be an effective means of bringing about good governance, development and poverty reduction (Chinsinga 2005). It has also been advocated as a means of "bring[ing] the government closer to the grassroots both in spatial and institutional senses' (Chinsinga 2005: 529) and to 'facilitate the utilisation of local peoples' knowledge about local conditions in solving local problems' (Yankson 2008: 230). However, efforts at decentralisation have not always been effective in achieving grassroots connections. Decentralisation involves allocation of powers to local bodies that may not themselves be 'downwardly accountable' (Ribot 2002). Elites often capture local power structures to sustain their rural power bases (Crook 2003). As a consequence, the input from, and benefits to, the 'grassroots' from decentralisation in Ghana were, for example, minimal (Mohan 1996). Indeed, ' $[t]$ he term 'decentralization' is ... often applied to programmes and reforms that ultimately are designed to retain central control' (Ribot 2002: v). Any positive impacts of decentralisation have also been somewhat undermined by the contemporaneous strengthening of civil society, as NGOs set up separate structures and have generally bypassed the structures and procedures of district level government (Mohan 2002).

The sectoral and scalar patterning of international development today is complex. The discussion above has tended to focus on broad scalar differences in how state and NGOs are imagined: the state as national and NGOs as both more local, and more international. An alternative way to explore the complexity is to imagine parallel sets of institutions in nested scales. Both governmental and non-governmental sectors are internally scaled with operations that might be classified as international, national or local as well as intervening scales such as supranational and subnational regions. One might, for instance, expect flows of funding to cascade from international to national to local level (in the case of this paper, from international donors, ultimately to schools). Yet the funding flows do not necessarily follow a predictable path. Figure one illustrates a web of relations of funding: each of the arrows might be illustrated using examples from Lesotho (both EU and USAID, for instance, bypass the 'national' level in providing small amounts of funding to local groups to undertake AIDS-related projects in schools). However, the diagram greatly simplifies the scalar-sectoral relationships. Many other organisations are also involved including churches, private and non-profit consultancy firms, parastatals, and authorities that bring together government, civil society and private sector representation. It is not only the sectors that are blurred, but, as the evidence presented later in this paper will demonstrate, the scales, too, are 
much more ambiguous than the chart suggests. Furthermore, the chart only maps funding and not flows of ideas and personnel.

[Figure I: funding flows - about here]

\section{Conceptualising scale}

In order to explore the scaling of interventions, it is useful to draw on a conceptual literature focused on scale that has developed in human geography over the past 20 years. The concept of scale has received attention from urban, political, economic, feminist and cultural geography (Marston et al 2005). It is a slippery concept: there is some debate as to scale's ontological status: whether scales materially exist or are merely epistemological phenomena, employed to categorise and impose a sense of order on the world. In either case, however, the scalar imagery we employ is not preordained (Marston 2000). Scale is socially constructed, and does not exist except through social practices (Herod and Wright 2002). Moreover, our use of scalar terminology very often connotes the character of the social, political and economic processes we perceive to occur across particular spaces (Brenner 200I): local economic processes are imagined to be quite different phenomena from those described by the term 'international economy'.

Geographers' interest in scale has escalated recently, in line with growing preoccupation with increasing global interdependence. The focus has been particularly on the global-local binary, especially in relation to processes of globalisation (Herod and Wright 2002), with the global understood as powerful (and thus important) and the local as relatively powerless (Baumann 1998; Gibson-Graham 2002). Often this binary is denied a meaningful spatiality: in relation to postcolonialism, 'the global is read as the (former or indirect) coloniser and the colonised is overdetermined as the "local" (Radcliffe 2000: 177). Yet it is important also to recognise that neither local nor global is a 'natural' scale (Pile 1997).

In practice, the local cannot be separated analytically from the global (North 2005). The two are only meaningful in relational terms. Although the global is often imagined as theoretically and empirically superior to the local, in practice they interpenetrate and overlap (Marston 2000). Globalisation is not 'a mono-directional implosion of global forces into sub-global realms' (Brenner 1997: 227). Decisions are made in very local boardrooms that have ramifications in countless places worldwide (Leitner and Miller 2007). For scholars such as Gibson-Graham (2002: 32 emphasis in the original), '[t]he global is local, in that it refers to processes that touch only certain 
(local) parts of the globe ... The local is global, and place is a 'particular moment' in spatialized networks of social relations'.

The notion that scale can be represented as a network confounds the local-global binary: no longer can one say a priori what is local and what is global. Instead the task is to trace the interaction of actual empirical relationships (Latham 2002). Furthermore, a network understanding of scale not only destabilises the local/global scalar binary, but also the notion of scale as a nested hierarchy, illustrated by the popular metaphor of Russian Matryoshka dolls in which each scale is separate and distinct but fits within larger and contains smaller scales (Herod and Wright 2002). In this view scale operates as both 'a system of territorial containers defined by absolute geographic size' and a hierarchical ordering of 'sociospatial processes, relations and interdependencies' (Brenner 200I: 606). In place of this nested territorial and hierarchical view, Massey (1998: 19, emphasis in the original) suggests that 'the social relations which constitute space are not organised into scales so much as into constellations of temporary coherence ...set within a societal space which is the product of relations and interconnections from the very local to the intercontinental'.

This view of space as comprising networks of relations downplays the existence of boundaries that define political units (Marston et al 2005). The extent to which bounded political territories retain significance is subject to dispute. For Cox (1998), it is possible to distinguish 'scales of dependence', defined in areal terms (such as the territory administered by a local state), from 'spaces of engagement', comprised of networks of associations which may extend beyond, or remain more localised than the spaces of dependence. In this view boundaries are porous, and political activity aimed at bringing change in a territorially defined unit may benefit from crossing those boundaries (Cox 1998). Others seek to move further from territorialised definitions. Latham (2002: 534), for instance, writes of '-scapes' which are 'patterns of thought, practices, and so forth that are no longer tightly tied to a single territory but are on the move, circulating through the world, separating and combining in complex and highly fluid ways'. This approach draws on Latour's (1996: 370) notion that societies have a 'fibrous, thread-like, wiry, stringy, ropy, capillary character that is never captured by the notions of levels, layers, territories, spheres, categories, structures, systems'.

There is another respect in which conventional notions of scale have been subject to critique. The dualistic conceptualisation of global and local scales is problematic not only due to its rigid hierarchy but also for its conflation with an abstract-concrete dualism, in which global phenomena 
are perceived as more abstract and less concrete than those deemed local. This is challenged by Massey (2005) and many others for whom the global is just as concrete as the local. As Katz (1993: 277) points out, 'structures are set in place and deployed locally and regionally by historical agents in their everyday lives'.

Marston et al (2005) take this further. In their view, untying local-global from concrete-abstract binaries is unlikely to be achieved by introducing the concept of networks (Marston et al 2005). Instead they propose to entirely abandon hierarchical scale in favour of a horizontal or site ontology in which the focus is on actual interactions, traceable through space. Drawing on Deleuze and echoing aspects of actor-network theory they put a case for studying humans and objects in interactions across multiple sites and argue that this offers greater opportunities for progressive politics, through enhancing connections between social sites (Marston et al 2005). This does not mean understanding the world in terms of free-flowing interaction: there are many forms of 'blockages, coagulations and assemblages' (Marston et al 2005: 423), material and discursive, that inhibit the fluidity of interrelations. Despite this valuable emphasis on resistance to interaction, and rejection of preconceived scales as a starting point for analysis, the notion of flat ontology has proven controversial, and there are a number of scholars for whom it implies an abandonment of necessary attention to the scalar structuration embedded in forms of contemporary social, political and economic practice (see for instance Hoefle 2006; Jonas 2006; Leitner and Miller 2007). As Paasi (2004) observes, networks matter but so do 'geography', boundaries and scales which serve to express and reinforce social practice, discourse and power.

In this paper I elaborate on how interventions are produced through networks of relations that operate through various sectors and across local and more distant spaces that are ultimately enacted in Lesotho's schools. While the metaphor of a web of flows proves very useful in making sense of the production of interventions, the idea of scalar hierarchies clearly inflects the structures of the organisations involved and their relationships with other organisations, and certain flows, notably of funding, persistently flow in one direction only.

\section{The research}

In order to make sense of the diverse, often contradictory processes through which interventions are produced, Perreault (2003: 603) calls for a 'fine-grained analysis of specific practices, discourses, and forms of organization'. The material presented here is the product of a series of more than 40 semi-structured interviews with officials (decision-makers and others) in government, international NGOs, donor agencies, UN agencies, local NGOs and churches who 
were engaged in AIDS-focused interventions in Lesotho schools. ${ }^{3}$ Organisations were identified through snowballing and include all the main donors, government ministries and international NGOs working in this area, alongside a selection of the many smaller civil society organisations. The focus on AIDS interventions in schools offers rich data. AIDS is a major concern to government, donor and NGO communities in Lesotho, and many different organisations are involved. The fact that these interventions are enacted through schools highlights collaboration between public sector and civil society, which has received relatively little attention in studies of development interventions. Interviews were considered the most appropriate method for this research as personal knowledge embodied in senior employees offers a more holistic lens onto organisational behaviour and interaction than textual data. While it has been possible to corroborate some of the findings by reference to documentary sources, the sheer volume of documents that pertain to organisations and their relationships is too large to be analysed without some guidance from those involved in their production and circulation. The interviews explored, among other questions, the involvement of organisations in instigating, providing funding for and implementing interventions; the forms of partnerships involved, and character of the relationships between the organisations. In particular, discussion focused on the interplay between 'international' actors and global discourses and local ideas and interests. The interviews were taped and transcribed, and analysis for this paper began with the identification of direct and indirect references to the relationships between different types of organisations and different (imagined or enacted) spatial scales. The transcripts were interrogated as representations of 'factual' information about the organisations and their relationships. Mindful of the fact that no interview is a simple transfer of information, the transcripts were approached as representing the personal viewpoints of differently positioned individuals, produced within the context of a research encounter that might have coloured the accounts presented. Comparisons have been drawn between accounts from different personnel (sometimes within a single organisation) to identify broad consistencies and inconsistencies between accounts. Importantly for this paper, the accounts presented are broadly illustrative of a range of similar stories, and the absolute 'truth' of any element of any story is of lesser importance than the wider picture conveyed through the set of narratives.

\footnotetext{
${ }^{3}$ Respondents occupied a range of managerial posts including the Principal Secretary of the Ministry of Education and Training, the United Nations Resident Representative in Lesotho, programme officers in NGOs and advisers in government agencies.
} 


\section{AIDS and the education sector in Lesotho}

Lesotho is a small, predominantly mountainous country with a population of two million, bounded on all sides by the Republic of South Africa. It has the third highest HIV prevalence in the world, with $23.2 \%$ of $15-49$ year olds infected (UNAIDS 2006). Rates of infection among the young are alarmingly high, especially among young women, with $5.9 \%$ of $15-24$ year old men and $14.1 \%$ of I524 year old women HIV positive (UNAIDS 2006).

AIDS impacts heavily on children, even though infection rates among those under I 5 remain low. Children are themselves vulnerable to infection, and 19\% of $0-17$ year olds have lost a parent, in most cases to AIDS (UNAIDS/UNICEF/USAID 2004). AIDS also impacts on school children in other ways. Many live in households that experience a loss of income when adults are too sick to work and require expensive care and funerals (Ntozi 1997). Many children are themselves required to care for sick relatives (Robson et al 2006). Children have to move home due to changes in the capacity of their households to provide care, or their help being required elsewhere (Ansell and van Blerk 2004). Those known to be affected by AIDS may suffer discrimination and stigma (Witter and Were 2004).

Many attempts to reduce infection and to respond to young people's needs have been introduced through Lesotho's education sector, as the vast majority of Lesotho's children attend primary school, and around half stay on to secondary school (Ansell 2002). Examples of interventions include the introduction of 'life skills education', designed primarily to encourage and enable young people to protect themselves in (or to avoid) sexual relationships; bursary schemes to ensure orphans and other vulnerable children are able to continue in school; provision of counselling for children affected by AIDS; and campaigns for the rights of children, particularly in relation to stigma and discrimination (Ansell 2008; Ansell in press). This paper explores how some of these interventions have been produced through relationships between organisations operating in different sectors and across scales.

\section{Lesotho's schools: sectoral and scalar complexity}

Before focusing closely on a selection of interventions, it is appropriate to examine the character of Lesotho's education system. Schools tend to be seen as public sector institutions, representative of national government, but looking closer the picture is less simple. Lesotho's education system is said to resemble a three-legged stool, resting equally on government, churches and communities. In terms of sector, there are some private and a very few government schools, but the vast majority of schools in Lesotho are owned by churches. The churches play a key role 
in the development and upkeep of buildings, provide school managers and are involved in the appointment of teachers. Meanwhile Government pays (most of) the teachers' salaries, controls curricula, examinations and textbooks, and trains the nation's teachers. Communities are represented on school committees but exercise little real influence. However, none of these three groupings is homogeneous or fully independent: all are influenced by other institutions.

Nor do schools exist at a single spatial scale. They are neither simply an arm of the national government, nor localised autonomous institutions. Schools employ - are officially required to deliver - centralised curricula, but these are selectively implemented. Schools are, nonetheless, driven by examination syllabuses as pass rates in examinations are used to measure the performance of both schools and teachers. Examination syllabuses continue to be validated by the University of Cambridge Local Examinations Syndicate (albeit with some input from the Lesotho government), an example of international influence penetrating directly into children's classrooms: the Lesotho state wishes its provision to be assessed on an international measure. Equally, aspects of the governance of education are devolved to the District level, and day-to-day operations reflect the actions of individual principals and teachers.

The churches that own the schools are also spatially structured - and each exhibits a quite different spatiality. The Catholic Church in Lesotho not only takes leadership from Rome but is well funded from overseas, especially Canada. The Anglican Church is part of the South African province and very integrated into South Africa; some AIDS-related initiatives brought into Anglican schools have been introduced to priests and teachers at meetings in South Africa. The Lesotho Evangelical Church, although it has origins in France (the Paris Evangelical Missionary Society), is now more of a national church.

Any activity in a school can therefore readily be analysed in terms of Massey's (1998) 'constellations of temporary coherence', impacted by events and processes in diverse places, near and far. Nonetheless, the imagined and enacted arrangement of practices at specifically local, district, national and international levels is of significance to what takes place. The schools in which AIDS interventions take place are thus already products of complex sectoral and scalar relations, even before other organisations arrive on the scene.

\section{Addressing AIDS in Lesotho's schools}

A wide range of actors play a part in shaping interventions intended to address AIDS in Lesotho's schools. These organisations take different roles, as funders, coordinators, subcontractors, sifters 
of proposals and implementing agencies. Actors involved in initiating developments include several government ministries (specifically Finance and Development Planning (MFDP), Health and Social Welfare (MoHSW), Education and Training (MOET) and Agriculture and Food Security (MOAFS)). All government ministries are required to devote $2 \%$ of their budgets to combating AIDS. The government has other arms and agencies including the Office of the First Lady which funds bursaries for orphans, the National Curriculum Development Centre and the Examinations Council of Lesotho which heavily influence what is taught in schools. Another parastatal was the Lesotho AIDS Programme Coordinating Authority (LAPCA), set up to coordinate the response to AIDS. This approved all government funded projects and programmes relating to AIDS, which included any funded by donors, as donor funding was channelled through government departments under the post-Washington agenda. A range of donors are involved including both multilateral (UNDP, UNICEF, WHO, UNAIDS, the World Bank) and bilateral agencies (principally Development Cooperation Ireland ( $\mathrm{DCl}$, now Irish Aid)), as well as the Global Fund. This organisation, itself heavily funded by the Gates Foundation, other organisations and bilateral donors, involves 'partnership between governments, civil society, the private sector and affected communities' (Global Fund 2008) and allocated \$12.5m for AIDS and TB to be channelled through Ministry of Finance to MoHSW (for TB), MOET (for prevention) and MOAFS (for mitigation). However, prior to releasing funds, the Global Fund required LAPCA to be replaced by a National AIDS Commission, fully independent of government and comprising representatives of civil society, the churches and the private sector, as LAPCA was perceived to operate as a barrier to implementation rather than a facilitator. Many international NGOs have instigated initiatives in schools, including Care and Population Services International (PSI), as have national NGOs and other CSOs such as Positive Action and Lesotho Save the Children. The churches play significant roles, as do youth organisations and teachers' unions. Finally, the selection of projects for funding is often undertaken by private consultancy organisations in Lesotho and elsewhere.

\section{Five cases}

The remainder of this paper will focus on five examples of organisations that are involved in intervening in Lesotho's schools in order to address problems associated with AIDS. The five organisations are PSI Lesotho; Care Lesotho-South Africa; the Lesotho Association of Teachers; Positive Action, Lesotho; and Lesotho Youth Federation. These were selected from the larger number in the original study in order to represent the diversity of civil society organisations engaged in AIDS-related interventions (they include two national/ regional offices of international NGOs, one trade union, one national NGO/ activist group, and one federation of youth organisations), and because they illustrate a range of ways in which the production of interventions 
crosses sectors and scales. In the sections below, I take each in turn and explore their intended interventions and how they negotiate with funders and with government departments (if at all) to get them implemented. The synopses presented here are based largely on the testimony of individual employees and volunteers, but strongly resonate with the many similar stories told by interviewees working in other organisations.

\section{I Population Services International (PSI)}

PSI offers an interesting example of the way in which organisations negotiate through different channels for funding and implementation. PSI is an international NGO with an office in Lesotho, and I interviewed the Marketing and Communications Manager, a South African. The organisation was in the process of introducing an abstinence campaign in schools with 10 to 16/17 year olds. The idea for this campaign came from PSI Lesotho, which approached the regional office in Johannesburg, South Africa. Having approved the project, that office searched for funding. PSI Lesotho was at the time in receipt of funding from the Dutch Government, the Global Fund, DCl and the United States Centres for Disease Control. Funding from bilateral donors is channelled through government, in this case through MoHSW (NGOs generally have contractual arrangements with one or more ministries). However, all AIDS-related projects require approval from LAPCA. LAPCA approval having been granted, the MoHSW put a recommendation to MOET to enable PSI to work with schools. At this stage, however, PSI elected not to approach schools directly, as the organisation is associated with condoms and liable to arouse hostility from churches (as owners of schools) and communities, as well as perhaps a negative response from schools themselves. Instead, they would approach the local communities via the chief or the church, in order to put their case and explain that they are promoting abstinence, before seeking access to the schools in which they wish to launch the campaign.

\subsection{Care Lesotho-South Africa}

Care Lesotho-South Africa is a cross-border branch within the southern African region of Care International. I interviewed the HIVIAIDS coordinator who is British born, but had lived in Lesotho since early childhood. Her post at Care was classified as an international post, although she had previously been employed in a national post in another international NGO in Lesotho, and international posts elsewhere in Africa.

Care's Sexual Health and Rights Promotion (SHARP) project, which includes the training of II-I4 year old peer educators, works by supporting the mobilisation of local civil society groups. These are relatively easy to mobilise in Lesotho as, unlike in South Africa, there is little expectation that 
the government will supply all needs. However, as an international NGO, Care finds it hard to access funds from international donors, which increasingly choose to channel all their funding through government. The Lesotho government is reluctant to fund international NGOs which they see as having external links of their own. For instance, the MoHSW wanted Care to pay them for providing training for CBO members, rather than seeing this as a government responsibility. Care Lesotho-South Africa had no current formal relationship with MoET, so chose to work at community and district levels, rather than national level. In terms of donors, it received some funding from the USAID Corridors of Hope programme and was applying for funding from the World Bank. This application, as with any for World Bank funding in Lesotho, would be screened by the South African office of Crown Agents (formerly a British public corporation, now a private sector international development company, operating worldwide) and if approved would be sent on to the World Bank headquarters in Washington for rubber stamping. It would then go to LAPCA for another stage of approval. Care was also in negotiations with the European Union for a civil society capacity building programme. This would be supported through a bilateral partnership with the Ministry of Development Planning.

\subsection{Lesotho Association of Teachers (LAT)}

LAT is the larger of two teachers' unions in Lesotho. I interviewed the HIVIAIDS Coordinator, a Mosotho. ${ }^{4}$ LAT is involved in a nine-country Education International (EI) collaboration ${ }^{5}$ that is training teachers to deliver life skills education in schools. Teachers are being trained to work with a manual that was developed by El (based in Brussels) and the World Health Organisation. The project in Lesotho has funding from the Dutch donor agency and has the cooperation of MoHSW and MoET. The HIVIAIDS Coordinator had been seconded by government to work with LAT, having previously worked with Peace Corps on life skills education. The scheme would involve a cascading delivery mechanism, with four 'Trainers of Trainers' trained from each district who each would in turn train twenty trainers from twenty schools in their district. These trainers would then deliver training to the remaining schools. The HIVIAIDS Coordinator was entirely unaware of the lifeskills curriculum initiative being developed by UNICEF and the MoET. It may be usual to view trade unions as representing civil society activism, but this intervention appears to lie at the intersection of government and international NGOs.

\footnotetext{
${ }^{4}$ Most residents of Lesotho are ethnically Basotho, singular Mosotho.

${ }^{5} \mathrm{El}$ is the international umbrella organisation of education unions.
} 


\subsection{Positive Action}

Positive Action Lesotho is a campaigning organisation of people living openly with AIDS. Its founder was a German long-time resident of Lesotho, who has since left the organisation. Positive Action achieved a high profile when it was able to access funds: it has received sponsorship from Care, Lesotho Planned Parenthood Association and DCl. I interviewed a Mosotho member of the organisation about their initiatives in schools.

Positive Action was involved in the development of youth corners in high schools, intended for informal discussion and provision of information on AIDS and sexual health, an idea that was taken up by UNAIDS. They also visited schools to screen and hold discussions on films from the Steps for the Future series (produced by a Finnish broadcasting company and Day Zero Film and Video from South Africa, with various funding). The organisation found it difficult to work with the MOET: the interviewee told me 'I don't think we can work together because we're volunteers, doing it from the heart; they're employees, just doing their job'. Unlike their NGO sponsors, the Ministry insists on going through protocol, which takes time.

\subsection{Lesotho Youth Federation (LYF)}

LYF is a federation of youth organisations in Lesotho. I conducted a group interview with three committee members, all of them young Basotho men, and also interviewed representatives of individual organisations that constituted the Federation. Youth organisations are mainly concerned with campaigning against stigmatisation and for the rights of children affected by AIDS. I was told that there were already many people engaged in awareness-raising in schools, but students are now aware of the epidemic and what they need to do to prevent it. The youth organisations' focus is instead on those affected, and specifically their rights.

The member organisations pay a small subscription and are assisted with fund-raising and income generation by the Federation to enable them to undertake projects. They had put funding proposals to embassies (including the UK, US, Irish and Canadian) and the MoHSW Department of Adolescent and Reproductive Health and also to the Firelight Foundation, a private charitable foundation founded in the US in 1999.

\section{Producing interventions through interaction}

The cases described above have illustrated some of the multi-scalar, multi-sectoral interactions that produce interventions. Interactions between individuals and flows of ideas and resources contribute in very clear ways to what happens in schools, although these flows are constrained by 
organisational structures and regulations. Scalar structures (both formal organisational structures, for instance relations between local and regional offices of NGOs, and assumptions concerning how people should interact) appear to play a variety of roles in shaping interactions, but do not constrain relationships to predictably ordered nested hierarchies. It is clear from the examples that there are some distinctions between different types of flows and interactions, and in the sections below the characteristics of flows of people and ideas will be examined separately from flows of money and regulations.

\section{I People and ideas}

Negotiations between organisations are invariably represented by people: individuals are important in initiating ideas and transforming or implementing them. While organisations and their branches might represent themselves as operating at a particular scale - international, regional, national, local - they often classify their staff in scalar terms too. Employees of UN and donor agencies and international NGOs are generally designated as either 'national' or 'international' staff, although the distinction is sometimes blurred. While in theory international staff are more senior and therefore more influential (and rewarded with much higher salaries ${ }^{6}$ ), they are often few in number and national staff may have responsibility in the relevant area. Furthermore, national staff also have local knowledge and connections that give them leverage. The international is thus not necessarily the more powerful of this pairing (cf Gibson-Graham 2002). The scalar binary doubtless shapes the production of interventions, but cannot do so in a rigidly deterministic way. 'International' staff are likely to originate outside the country in which they work (although this is not always so, as the example from Care demonstrates). They are likely to be from the rich world (and in the case of bilateral donor agencies usually come from the donor nation), but those working for UN agencies often hail from other African nations: the UN resident representative in Lesotho, for instance, was Kenyan. It is noteworthy that people also move between scales, as they are promoted through the hierarchies of organisations.

Government, too, makes some distinction between civil servants based in the capital and those in the districts. While not having a specific cadre of international staff, not all those working for the Lesotho government are Lesotho nationals: a number of donors provide 'technical assistance' in the form of ministry-based advisors originating from overseas. The 'national ownership' that is the aspiration of the post-Washington consensus is thereby directly disrupted by the movement of individuals that accompanies the policies associated with that approach. There is also very

\footnotetext{
${ }^{6}$ The salary differences within organisations may be easier to justify in relation to 'national' and 'international' labels than by reference to the expatriate status of the better paid employees.
} 
considerable movement of individuals between sectors. The head of Lesotho's civil service, for instance, has, in the past 20 years, occupied senior posts in the university, UNICEF (a 'national' post), a regional development consultancy firm and the civil service, and also owns an NGO. Such intersectoral movement is far from unusual. Webs of interaction between people, then, are multiple and complex. Individuals move through differently located posts, but the location of posts and their relation to one another is partly tied to scalar frameworks which affect the ways in which the people in the posts (are able to) relate to one another and influence the production of interventions.

Irrespective of their own backgrounds, all individuals are subject to influences of local and nonlocal (international) provenance. Decisions that are taken within and between organisations are influenced by individuals whose knowledge, values and motivations are diverse. Often it is personal experience that motivates those working in the civil service, NGOs or wider civil society to take action in relation to AIDS. The propagation of ideas is also important. As Mawdsley et al (2002) point out, NGOs have come together worldwide as a transnational community held together by face-to-face encounters, a shared NGO language, flows of money and transmission of information, particularly by email and internet. There is undoubtedly considerable dialogue among an elite that brings together people from Western countries, other African countries and Lesotho, with a high take-up of ideas often filtered through literature produced by UN agencies. The circulation of these ideas is reinforced through the significance donors attach to immersion in the prevailing discourse. Arguably access to information loops has become more important to the success of NGOs in gaining funding than making a difference to the lives of their clients (Mawdsley et al 2002).

There is a widespread belief that NGOs are 'closer' to the poor, and aware of the viewpoints and interests of local communities (Clark 1991). Yet NGOs often congregate close to cities and fail to extend into poorer regions (Edwards and Hulme 1995). Neither does decentralisation necessarily serve the interests of ordinary people: 'While local politics can often be found at the regional, national or global scale, what takes place at the local level may not be local politics at all but the localization of wider political games involving regional, national or global actors who have found local venues to mine and local actors to express their interests' (Smith 1998: 39-40). In relation to AIDS interventions in schools, there is very little consultation though at grassroots level, as the following extract from an interview with the Lesotho Country Programme Advisor for UNAIDS reveals: 
Q: I was just wondering whether there were local ideas coming up, or whether it's a case of trying out things that have been tried elsewhere?

$R$ : Probably $99 \%$ it is trying things that have worked elsewhere.

Q: And they are tried and evaluated, rather than there being a consultation with grass roots people to start with?

R: They have been tried; I mean the things that have worked elsewhere. Just transplanting and giving them a chance here in Lesotho.

As has been hinted above, it is important to recognise that organisations are more than the people who work in them. The ways in which people are brought together in organisations, and the mechanisms through which those organisations interact with one another (in turn reflecting other flows and interactions) inflect the activities they engage in. While these interactions are fluid and may usefully be analysed as a form of web, people and ideas move more readily along some channels than others. There is a clear scalar dimension to this, particularly when considering how interventions are produced for enactment across the national territory. In general the guiding templates for interventions are introduced from beyond the nation's boundaries, whether from the international NGO community or elsewhere (even those that are said to have a local origin are based on models encountered elsewhere). The international is accorded a higher status than the national or local. Ultimately of course, these ideas, like any other, come from small numbers of people in particular places (in turn influenced by ideas from other people in other places): they are not fundamentally 'global ideas'. However, the fact that in Lesotho interventions draw on ideas from beyond the national borders is not accidental: it is the outcome of a purposive engagement with what is recognised and valued (within a classic scalar hierarchy) as an international sphere.

\subsection{Money and regulation}

Civil society and the state are closely intertwined in most responses to AIDS in Lesotho's schools. The government is seldom permitted by donors to act independently: one of the conditions for receiving aid is to work with partners. Equally, it is hard for civil society to operate in schools without government sanction (and cooperation). There are protocols that govern these relationships and most funding is channelled directly or indirectly through government.

Almost all initiatives in schools require funding. Major initiatives need major funding. Programmes are scrutinised by donors and the national-level agency, LAPCA, which are embedded in global discourse as well as being influenced by the views and motivations of individuals. Smaller initiatives require smaller funds. Of the five cases outlined above, the one that was apparently most 
responsive to local needs (to the views of school students) was the Lesotho Youth Federation. This national organisation did not receive sufficient funding to fall under the scrutiny of LAPCA but, ironically, was approaching donors based overseas which had no local representation.

Flows of funds are not simply negotiated between two organisations. Mediating organisations intervene and may operate in a different sector in a different scalar relationship, as for instance where decisions are filtered by Crown Agents or by LAPCA. The requirements of funding bodies constrain directly the interventions that are permissible, but also bring in the scrutiny of other, differently placed individuals and groups. While interventions do not cascade, fully formed, down a hierarchy of scales from international to local in a single direction, funding does follow a unilinear trajectory. Funds for AIDS-related interventions come, almost exclusively, from overseas. Such financial flows inevitably underpin dependencies and ensuing power relations. Although governments' power in relation to NGOs has increased under the new aid regimes, and governments may deliberately or inadvertently coopt NGOs, preventing them from pursuing their own concerns (Clark 1995), governments are highly dependent on donor funding. Most partnerships in practice are facades and conceal highly asymmetrical power relations (Mawdsley et al 2002). The flows of finance that help produce interventions are fluid and not always predictable, but they are not arbitrary: they follow and reinforce differentials of power.

\section{Conclusions: a different place for scale}

Since the 1980s, development interventions have involved complex interactions between donors, governments and NGOs. In the era of the post-Washington consensus and Paris Declaration these interactions have become more complex still, with a range of actors involved at multiple stages of the development and implementation of an intervention. The assertion of fundamental differences between state and civil society is undermined by the flow of personnel and ideas. Inventions are neither the products of a single organisation nor a single scale. The arguments that state and NGOs are tightly interwoven (Mercer 2002) and that taking the single NGO as a unit of analysis is unhelpful (Bebbington 2004) are not new. However, while Radcliffe (2004) has pointed out that geographers have much to offer development thinking in relation to scale, little empirical work has hitherto examined the scaling of development interventions.

In this paper I have considered how interventions intended to address AIDS in schools often appear to emerge from organisations that are mandated to operate across territories defined in scalar terms: international, national or local. While labelling NGOs as 'northern' or 'southern' offers a slightly different spatial imagery, northern NGOs are generally conceived as operating 
more extensively across international borders, whereas southern NGOs are generally confined to one or few nations. In practice, however, interventions are produced through flows of ideas, instructions, personnel and funding that are not confined to a particular scale or level. The existence of these flows points to the value of thinking about spatial relationships in terms of networks of interactions and flows, as advocated in much of the growing literature on scale discussed earlier in this paper. Furthermore, the case studies provided highlight the ways in which interactions and flows are grounded, and not merely abstract structural relationships (Massey 2005). Most (although not all) of the 'international' scale donors and NGOs involved with AIDS and education exist 'on the ground' in Lesotho, and all negotiations are played out in concrete (or sometimes virtual) space, sometimes many times over for an intervention that involves multiple parties in shaping, funding and implementation.

Nonetheless, the examples also highlight (as Paasi 2004 argues) how territorially imagined scale remains important, in part because the scalar structuring of organisations and practices shapes flows and interactions. Organisations have their own internal scalar structures - nested hierarchies are often fundamental to their organisational form - and it is expected that particular forms of information and resources should flow in particular directions and take particular routes. While these flows exist materially, the channels along which they flow are moulded in large part by organisational charts but also by unspoken understandings. Interventions themselves are also often structured in relation to scalar hierarchies - as in the cascading workshops organised by LAT.

While ideal forms of scalar structure may exist on paper and give shape to interventions, the examples provided highlight the crucial fact that they do not stand alone, and the interventions that emerge from them cannot be understood without looking at interaction beyond the discrete scalar structure. To better reflect the pattern on the ground in Lesotho, Figure I would need to include not only a wider variety of types of organisation and types of flow, but also other orderings or structures partly governing those flows. Organisations and projects, particularly if they operate through the school sector, do not operate in isolation, but rather various distinct (if hierarchically structured) organisations interact in complex ways. Davies (2002: 525) writes of 'the heterarchical nature of aid supply chains. Individual NGOs often belong, through their donors, to more than one hierarchy of organizations, each with differing strategic objectives and priorities'. Owing to this complex interbedding, flows of ideas and resources are seldom unilinear, always moving from larger to smaller scales along defined pathways. Relationships between international NGOs (eg Care) and local groups, particularly if they use assistance from international donors, are often mediated by government. On the other hand, relationships between international donors 
and local groups may bypass government and the 'national' level, but are sometimes mediated by consultancies based overseas. Thus in seeking to understand the complex flows that produce particular interventions, especially in post-Washington times, a 'Russian doll' image of scale certainly does not correspond to practice on the ground. However, it may be helpful to imagine a metaphor in which a multiplicity of intersecting Russian dolls constitute part of the framework on which a web or a network hangs, opening up some unexpected channels and closing others down.

There are a number of implications that can be drawn from this paper for those interested in development interventions such as those being enacted in Lesotho's schools in response to the AIDS pandemic. First, it is unhelpful to make assumptions about the roles of particular types of organisation, how close they are to ordinary people, or where their ideas come from, or to assume that interventions promoted by particular types or 'scales' of organisation are more foreign or more local than others. Secondly, there is likely to be considerable value to focusing not on the organisations between which people, information, instructions and money flow and from which interventions ostensibly emanate, but rather on the flows themselves that constitute the organisations and their actions. Thirdly, although interventions may be outcomes of webs that hang in part on scalar frameworks, those frameworks are highly diverse. Furthermore, scales are never fixed - they are perpetually redefined and restructured (Swyngedouw 1997). The scalar structures organisations employ are generally of their own making. Although individuals and organisations are constrained by spatial structures, they are also implicated in their production may be enabled by them (Leitner and Miller 2007). If scales are socially constructed they can be done differently.

There are also lessons for the theorisation of scale. The paper has demonstrated the value of thinking of the spatial relations that produce interventions in terms of a web of flows, and draws attention to the different characteristics of different forms of flows, some of which are more constrained than others. The paper also cautions against dismissing the significance of scale as part of the framework on which such webs hang. These frameworks relate to multiple superimposed scalar structures of diverse forms - some binary, some nested, some entrenched in ideology, some represented in organisational diagrams, some played out across territories. Keith and Pile (1993: 224) point to the 'simultaneously real, imaginary and symbolic' character of social space. Both the imagery and symbolism of scales are very influential in shaping the thought and actions of many organisations involved in development interventions. Massey (2005: 10I) stresses that localised organisations and events 'are differently located within wider power-geometries': those geometries incorporate scalings that both reflect and tend to reinforce power relations. On this 
basis, 'recognition of scalar orders and existing power asymmetries is crucial to a progressive politics, both in terms of the development of alternative political spaces and the deployment of socio-spatial strategies of resistance' (Leitner and Miller 2007: I2I).

\section{Acknowledgements}

The author gratefully acknowledges the support of an RGS-IBG small grant, provided by Mrs Pamela Savage, for the wider research project on which this paper is based.

\section{References}

Ansell N 2002 "Of course we must be equal, but ...': imagining gendered futures in two rural southern African secondary schools' Geoforum 33, 179-194

Ansell N 2008 'Substituting for families? Schools and social reproduction in AIDS-affected Lesotho' Antipode 40(5), 802-824

Ansell $\mathrm{N}$ in press 'Embodied learning: responding to AIDS in Lesotho's education sector' Children's Geographies

Ansell $\mathrm{N}$ and van Blerk L 2004 'Children's migration as a household/family strategy: coping with AIDS in Malawi and Lesotho' Journal of Southern African Studies 30(3), 673-690

Armon J 2007 'Aid, politics and development: a donor perspective' Development Policy Review 25(5), 653-656

Baumann Z 1998 Globalization: the human consequences Columbia University Press, New York

Bebbington A 2004 'NGOs and uneven development: geographies of development intervention' Progress in Human Geography 28(6), 725-745

Brenner N 1997 'State territorial restructuring and the production of spatial scale: urban and regional planning in the Federal Republic of Germany, 1960-1990' Political Geography 16(4), 273-306

Brenner N 200I 'The limits to scale? Methodological reflections on scalar structuration' Progress in Human Geography 25(4), 59I-6I4

Brown A, Foster M, Norton A and Naschold F 200I The status of sector wide approaches, Overseas Development Institute, London

Buchert L 2002 'Towards new partnerships in sector-wide approaches: comparative experiences from Burkina Faso, Ghana and Mozambique' International Journal of Educational Development $22,69-84$

Cassels A and Janovsky K 1998 'Better health in developing countries: are sector-wide approaches the way of the future?' Lancet 352(9|42), 1777-1779 
Chinsinga b 2005 'District Assemblies in a fix: the perils of the politics of capacity in the political and administrative reforms in Malawi' Development Southern Africa 22(4), 529-548

Clark J D 199I Democratizing development: the role of voluntary organizations, Earthscan, London

Clark J D 1995 'The state, popular participation and the voluntary sector' World Development 23(4), 593-60।

Cox K R 1998 'Spaces of dependence, spaces of engagement and the politics of scale, or: looking for local politics' Political Geography 17(1), I-23

Crook R C 2003 'Decentralisation and poverty reduction in Africa: the politics of local-central relations' Public Administration and Development 23(I), 77-88

Davies R 2002 'Monitoring and evaluating NGO achievements' in Potter R B (ed) The companion to development studies Arnold, London, Pp. 523-528

DFID 2000 Eliminating world poverty: making globalisation work for the poor. White Paper on International Development, The Stationery Office, Norwich

Edwards M and Hulme D (eds) 1995 NGO performance and accountability: beyond the magic bullet Earthscan, London

Elsey H, Kilonzo N, Tolhurst R and Molyneux C 2005 'Bypasing districts? Implications of sectorwide approaches and decentralization for integrating gender equity in Uganda and Kenya' Health Policy and Planning 20(3), I50-157

Fine B 200I 'Neither the Washington nor the post-Washington consensus: an introduction' in Fine B, Lapavitsas C and Pincus J (eds) Development policy in the twenty-first century: beyond the post-Washington consensus Routledge, London, Pp. I-27

Fowler A 1988 Non-Governmental Organisations in Africa: achieving comparative advantage in relief and micro-development, Institute of Development Studies, Brighton

Fowler A 2000 'Beyond partnership: getting real about relationships in the aid system' IDS Bulletin $3 I(3)$

Gibson-Graham J K 2002 'Beyond global vs. local: economic politics outside the binary frame' in Herod A and Wright M W (eds) Geographies of power: placing scale Blackwell, Oxford, pp. $25-60$

Global Fund 2008 'How the Global Fund works', accessed I5/03/2008, http://www.theglobalfund.org/en/about/how/

Goetz A M 1996 'Local heroes: patterns of field worker discretion in implementing GAD policy in Bangladesh' IDS Discussion Paper 358

Herod A and Wright M W 2002 'Placing scale: an introduction' in Herod A and Wright M W (eds) Geographies of power: placing scale Blackwell, Oxford, Pp. I-I4 
Hill P S 2002 'The rhetoric of sector-wide approaches for health development' Social Science and Medicine 54(I I), I725-1737

Hoefle, S W 2006 'Eliminating scale and killing the goose that laid the golden egg?' Transactions of the Institute of British Geographers 31, 238-243

Hudock A C 1999 NGOs and civil society: democracy by proxy? Polity, Cambridge

Hulme D and Edwards M (eds) 1997 NGOs, states and donors: too close for comfort? St Martin's, New York

Jonas A E G 2006 'Pro scale: further reflections on the 'scale debate' in human geography' Transactions of the Institute of British Geographers 31, 399-406

Katz C 1993 'Growing girls/closing circles: limits on the spaces of knowing in rural Sudan and United States cities' in Katz C and Monk J (eds) Full circles: geographies of women over the life course Routledge, London

Keith M and Pile S 1993 'Conclusion: towards new radical geographies' in Keith M and Pile S (eds) Place and the politics of identity Routledge, London, I-2 I

Latham A 2002 'Retheorizing the scale of globalization: topologies, actor-networks, and cosmopolitanism' in Herod A and Wright MW (eds) Geographies of power: placing scale Blackwell, Oxford, pp. II5-144

Latour B 1996 'On actor-network theory: a few clarifications' Soziale Welt 47(4), 369-38I

Lawson V 2007 Making development geography Hodder Arnold, London

Leitner H and Miller B 2007 'Scale and the limitations of ontological debate: a commentary on Marston, Jones and Woodward' Transactions of the Institute of British Geographers 32, II6125

Lewis D 1998 'Development NGOs and the challenge of partnership: Changing relations between north and south' Social Policy and Administration 32(5 SUPPL.2), 50 I-5 I 2

Lister S and Nyamugasira W 2003 'Design contradictions in the 'new architecture of aid'? Reflections from Uganda on the roles of civil society organisation' Development Policy Review $21(1), 93-106$

Marston S A 2000 'The social construction of scale' Progress in Human Geography 24(2), 219-242

Marston S A, Jones J P I and Woodward K 2005 'Human geography without scale' Transactions of the Institute of British Geography 30, 4I6-432

Massey D 1998 'The spatial construction of youth cultures' in Skelton T and Valentine G (eds) Cool places: geographies of youth cultures Routledge, London

Massey D 2005 For space Sage, London

Mawdsley E, Townsend J G, Porter G and Oakley P 2002 Knowledge, power and development agendas: NGOs North and South INTRAC, Oxford 
Mercer C 2002 'NGOs, civil society and democratization: a critical review of the literature' Progress in Development Studies 2(I), 5-22

Mercer C 2003 'Performing partnership: civil society and the illusions of good governance in Tanzania' Political Geography 22(7), 74I-763

Mohan G 1996 'Neoliberalism and decentralised development planning in Ghana' Third World Planning Review 18(4), 433-454

Mohan G 2002 'The disappointments of civil society: the politics of NGO intervention in northern Ghana' Political Geography 2I(I), I25-I54

Närman A 1999 'Getting towards the beginning of the end for traditional development aid: major trends in development thinking and its practical application over the last fifty years' in Simon D and Närman A (eds) Development as theory and practice Longman, Harlow, Pp. $149-180$

North P 2005 'Scaling alternative economic practices? Some lessons from alternative currencies' Transactions of the Institute of British Geographers 30, 22I-233

Ntozi J P M 1997 'Effect of AIDS on children: the problem of orphans in Uganda' Health Transition Review 7(supplement), 23-40

Olowu B 200I 'African decentralisation policies and practices from 1980s and beyond' Institute of Social Studies Working Paper 334

Paasi A 2004 'Place and region: looking through the prism of scale' Progress in Human Geography 28(4), 536-546

Perreault 2003 "A people with our own identity': toward a cultural politics of development in Ecuadorian Amazonia' Environment and Planning D: Society and Space 21, 583-606

Pile S 1997 'Introduction: opposition, political identities and spaces of resistance' in Pile S and Keith M (eds) Geographies of resistance Routledge, London, Pp. I-32

Quartey P 2005 'Innovative ways of making aid effective in Ghana: tied aid versus direct budgetary support' Journal of International Development 17, 1077-1092

Radcliffe S A 2000 'Entangling resistance, ethnicity, gender and nation in Ecuador' in Sharp J P, Routledge P, Philo C and Paddison R (eds) Entanglements of power: geographies of domination/resistance Routledge, London, Pp. 164-181

Radcliffe S A 2004 'Geography of development: development, civil society and inequality - social capital is (almost) dead?' Progress in Human Geography 28(4), 517-527

Ribot J C 2002 'African decentralization: local actors, powers and accountability in a review of issues' UNRISD Programme on Democracy, Governance and Human Rights, Paper Number 8 
Robson E, Ansell N, Huber U, Gould W and van Blerk L 2006 'Young caregivers in the context of the HIVIAIDS pandemic in sub-Saharan Africa' Population, Space and Place I2(2), 93-I I I

Simon D and Närman A 1999 'Conclusions and prospects' in Simon D and Närman A (eds) Development as theory and practice Longman, Harlow, Pp. 269-275

Smith H 2005 'Ownership and capacity: do current donor approaches help or hinder the achievement of international and national targets for education?' International Journal of Educational Development 25, 445-455

Smith M P 1998 'Looking for the global spaces in local politics' Political Geography I7(I), 35-40

Sperfeld R 2006 'Decentralisation and the establishment of local government in Lesotho' Diplomarbeit, Universität Potsdam

Swyngedouw E 1997 'Neither global nor local: 'Glocalization' and the politics of scale' in Cox K (ed) Spaces of globalization: reasserting the power of the local, Guilford Press, New York, I37166

UNAIDS 2006 Report on the global AIDS epidemic UNAIDS, Geneva

UNAIDS/UNICEF/USAID 2004 Children on the brink: $a$ joint report of new orphan estimates and a framework for action, New York

Unwin T 2004 'Beyond budgetary support: pro-poor development agendas for Africa' Third World Quarterly 25(8), I50I-1523

White H 2007 'The Bangladesh health SWAp: experience of a new aid instrument in practice' Development Policy Review 25(4), 45 I -472

Witter S and Were B 2004 'Breaking the silence: using memory books as a counselling and succession-planning tool with AIDS-affected households in Uganda' African Journal of AIDS Research 3(2), 139-143

Yankson P W K 2008 'Decentralisation and poverty reduction in the Gomoa District of Ghana' Norsk Geografisk Tiddskrift 62(3), 230-240 